\title{
Squamous Cell Carcinoma of the Lung Producing Granulocyte Colony-Stimulating Factor and Resembling a Malignant Pleural Mesothelioma
}

\author{
Yoshihiro KoвASHI, Niro OKIMOTO* and Kazuhiro SAKAмотO**
}

\begin{abstract}
A 65-year-old was admitted to our hospital and was diagnosed as having squamous cell carcinoma originating in the right upper bronchus. He underwent both chemotherapy and radiation therapy, but these therapies were ineffective and thereafter the developed radiation pneumonitis and carcinomatous pleuritis. Finally, he died of bacterial pneumonia in the opposite normal lung of four months duration. From one month before his death, laboratory data indicated marked leukocytosis, and his granulocyte colony-stimulating factor (G-CSF) serum level was high. At autopsy, squamous cell carcinoma was found in the right hilus region of the lung, with a spreading form resembling a malignant pleural mesothelioma mainly occupying the pleural cavity. Based on positive staining method with specific monoclonal antibodies against G-CSF, it was considered that the leukocytosis was caused by G-CSF producing tumor.
\end{abstract}

(Internal Medicine 43: 111-116, 2004)

Key words: squamous cell carcinoma, leukocytosis, G-CSF, malignant pleural mesothelioma

\section{Introduction}

Recently, several cases of leukocytosis in lung cancer patients caused by granulocyte colony-stimulating factor (GCSF)-producing tumors have been reported $(1,2)$. In the past, primary lung cancers closely mimicking malignant pleural mesotheliomas have often been compared with malignant pleural mesotheliomas. This histological diagnosis is frequently made in cases of adenocarcinoma of the lung, and the differential diagnosis is difficult $(3,4)$. We describe a rare case of squamous cell carcinoma of the lung producing G-CSF and resembling a malignant pleural mesothelioma.

\section{Case Report}

A 65-year-old man with a 30-cigarette per day smoking history of 40 years was admitted to our hospital for fever and cough on January 20, 1999. He had no past medical or family history of cancer. His physical examination was unremarkable. His temperature was $36.2^{\circ} \mathrm{C}$; pulse, 64 beats/min; respiration, $22 \mathrm{breath} / \mathrm{min}$ and blood pressure, 140/72 $\mathrm{mmHg}$. The conjunctiva palpeblae were slightly anemic, but no peripheral lymphadenopathy or hepatosplenomegaly was present.

Laboratory data on admission are shown in Table 1. A peripheral blood examination included a red blood cell count of $335 \times 10^{4} / \mu \mathrm{l}$; hemoglobin, $10.4 \mathrm{~g} / \mathrm{dl}$; and a white blood cell count of $100 \times 10^{2} / \mu \mathrm{l}$ (76.4\% neutrophils, $15,4 \%$ lymphocytes, $6.4 \%$ monocytes, $1.6 \%$ eosinophils, $0.2 \%$ basophils). Inflammatory responses included C-reactive protein, 3.57 $\mathrm{mg} / \mathrm{dl}$ and an erythrocyte sedimentation rate of $95 \mathrm{~mm} / \mathrm{h}$. Chemical screening included serum albumin, $3.2 \mathrm{~g} / \mathrm{dl}$; globulin, $4.7 \mathrm{~g} / \mathrm{dl}$; and blood sugar, $148 \mathrm{mg} / \mathrm{dl}$. Among tumor markers, only SCC was elevated $(2.2 \mathrm{ng} / \mathrm{ml})$. A sputum cytologic examination showed suspected squamous cell carcinoma, A chest X-ray film on admission (Fig. 1) demonstrated a mass shadow in the upper portion of the right hilum. Chest computed tomography (CT) on admission (Fig. 2) revealed a mass shadow $(>3 \mathrm{~cm})$ corresponding to the right main bronchus and obstructive pneumonia in the upper lobe of the right lung. However, there was no right pleural effusion.

Bronchoscopic findings (Fig. 3) disclosed compression from the right side of the right main bronchus, and an irregu-

From the Division of Respiratory Diseases, Department of Medicine, Kawasaki Medical School, Kurashiki, *the Division of Respiratory Diseases, Department of Medicine, and **Department of Pathology, Kawasaki Medical School Kawasaki Hospital, Okayama

Received for publication May 12, 2003; Accepted for publication August 29, 2003

Reprint requests should be addressed to Dr. Yoshihiro Kabashi, the Division of Respiratory Diseases, Department of Medicine, Kawasaki Medical School, 577 Matsushima, Kurashiki 701-0192 
KoBASHI et al

Table 1. Laboratory Data on Admission

\begin{tabular}{|c|c|c|c|}
\hline \multicolumn{2}{|c|}{ Peripheral blood } & \multicolumn{2}{|l|}{ Mineral } \\
\hline $\mathrm{RBC}$ & $335 \times 10^{4} / \mu 1$ & $\mathrm{Na}$ & $136 \mathrm{mEq} / \mathrm{l}$ \\
\hline $\mathrm{Hb}$ & $10.4 \mathrm{~g} / \mathrm{dl}$ & $\mathrm{K}$ & $3.7 \mathrm{mEq} / \mathrm{l}$ \\
\hline $\mathrm{Ht}$ & $33.0 \%$ & $\mathrm{Cl}$ & $96 \mathrm{mEq} / \mathrm{l}$ \\
\hline WBC & $10,000 / \mu 1$ & & \\
\hline Neutro & $76.4 \%$ & Serological test & \\
\hline Lym & $15.4 \%$ & CRP & $3.57 \mathrm{mg} / \mathrm{dl}$ \\
\hline Mono & $6.4 \%$ & ESR & $95 \mathrm{~mm} / \mathrm{h}$ \\
\hline Eosino & $1.6 \%$ & RA & $(-)$ \\
\hline Baso & $0.2 \%$ & & \\
\hline \multirow[t]{2}{*}{ Plate } & $40.3 \times 10^{4} / \mu 1$ & Tumor marker & \\
\hline & & AFP & $5 \mathrm{ng} / \mathrm{ml}$ \\
\hline \multicolumn{2}{|c|}{ Chemical screening } & CEA & $3.8 \mathrm{ng} / \mathrm{ml}$ \\
\hline SP & $7.9 \mathrm{~g} / \mathrm{dl}$ & SCC & $2.2 \mathrm{ng} / \mathrm{ml}$ \\
\hline Alb & $3.2 \mathrm{~g} / \mathrm{dl}$ & CYFRA 21-1 & $3.4 \mathrm{ng} / \mathrm{ml}$ \\
\hline $\mathrm{Glb}$ & $4.7 \mathrm{~g} / \mathrm{dl}$ & SLX & $36.0 \mathrm{U} / \mathrm{ml}$ \\
\hline $\mathrm{BS}$ & $148 \mathrm{mg} / \mathrm{dl}$ & NSE & $9.5 \mathrm{ng} / \mathrm{ml}$ \\
\hline ALP & $365 \mathrm{IU} / \mathrm{l}$ & Pro GRP & $28.5 \mathrm{ng} / \mathrm{ml}$ \\
\hline LDH & $320 \mathrm{IU} / \mathrm{l}$ & & $0 \times 0$ \\
\hline$\gamma$-GTP & $17 \mathrm{IU} / l$ & PPD & $\overline{14 \times 18}$ \\
\hline $\operatorname{Bil}(\mathrm{T})$ & $0.5 \mathrm{mg} / \mathrm{dl}$ & & \\
\hline $\mathrm{ChE}$ & $251 \mathrm{IU} / \mathrm{l}$ & Sputum & Culture: MSSA (+) \\
\hline GPT & $18 \mathrm{IU} / \mathrm{l}$ & & AFB: smear (-), culture $(-)$ \\
\hline GOT & $23 \mathrm{IU} / \mathrm{l}$ & & Cytology: Class IV (Squamous cell Ca sp. \\
\hline $\mathrm{Crn}$ & $0.7 \mathrm{mg} / \mathrm{dl}$ & & \\
\hline BUN & $11 \mathrm{mg} / \mathrm{dl}$ & PFT & \\
\hline UrA & $5.1 \mathrm{mg} / \mathrm{dl}$ & $\% \mathrm{VC}$ & $72.0 \%(\mathrm{VC} 2.36 l)$ \\
\hline \multirow[t]{2}{*}{ Amy } & $86 \mathrm{IU} / l$ & $\mathrm{FEV}_{1.0} \%$ & $65.8 \%\left(\mathrm{FEV}_{1.0} 1.77 l\right)$ \\
\hline & & $\%$ DLco & $60.9 \%(\mathrm{DLco} 14.70 \mathrm{ml} / \mathrm{min} / \mathrm{mmHg}$ ) \\
\hline
\end{tabular}

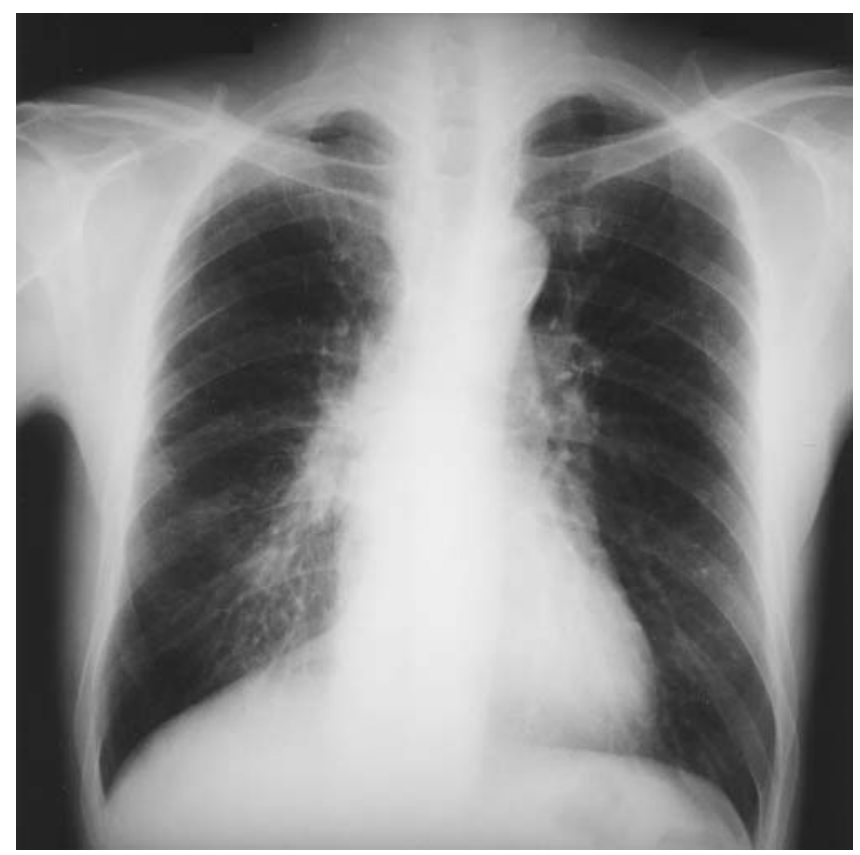

Figure 1. Chest X-ray film on admission showing a mass shadow a mass shadow in the upper part of the right hilum.

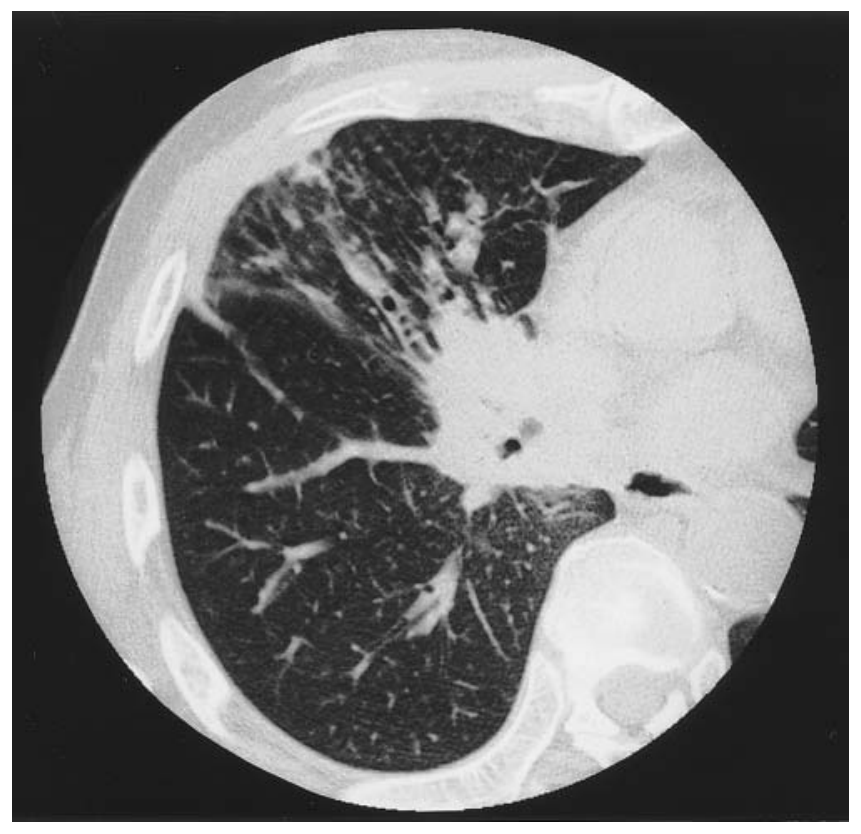

Figure 2. Chest CT scan on admission showing a mass shadow corresponding to the right main bronchus and obstructive pneumonia in the upper lobe of the right lung. 


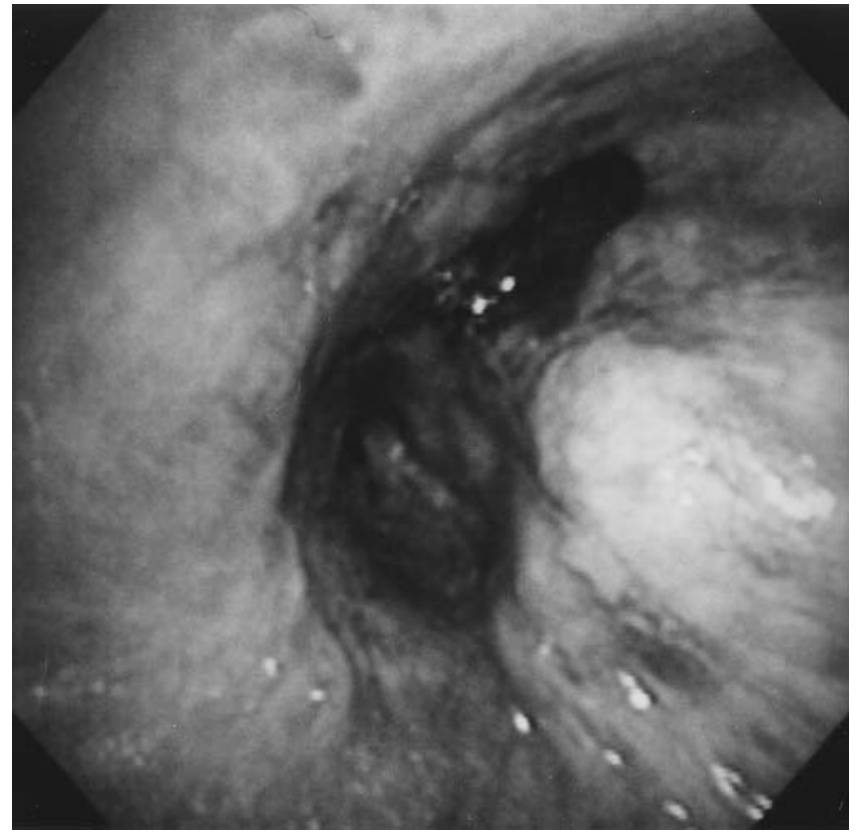

Figure 3. Bronchoscopic findings showing a compression from the right side of the right main bronchus and an irregular mass completely occluding the entrance of the right upper lobe.

lar mass completely occluded the entrance of the right upper lobe. Transbronchial biopsy specimens from these lesions showed histologic findings of moderately differentiated squamous cell carcinoma.

The patient's clinical course is shown in Fig. 4. We diagnosed squamous cell carcinoma of the lung originating from the right upper bronchus complicated by obstructive pneumonia after admission (T2N3M0, Stage III B), and started chemotherapy using cisplatin and docetaxel and radiation for the right hilum on January 26, 1999. The treatment was clinically ineffective, since there was no change in the tumor size on chest CT and an irregular mass occluded the bronchus of the right upper lobe on bronchoscopic findings as it had before treatment. However, his condition was complicated by radiation pneumonitis corresponding to the radiation area on March 3 (Fig. 5). Although a corticosteroid drugs was not administered, an antipyretic analgesic agent was given and he was discharged on March 21. Later, he was again admitted to our hospital for fever, cough, and dyspnea due to massive right pleural effusion. Carcinomatous pleuritis was thought to have developed during the detection of squamous cell carcinoma through cytological examination of right pleural effusion. Because his white blood cell count was elevated, $17,500 / \mu \mathrm{l}$ to $66,200 / \mu \mathrm{l}$ within one week and continued until death. Suspecting a G-CSF-producing tumor, we measured serum G-CSF and subsequently found it to be elevated to $135 \mathrm{pg} / \mathrm{ml}$. Afterwards, as treatment for the patient's massive pleural effusion, $0 \mathrm{~K}-432$ and adriamycin were administered into the right pleural space after insertion of a pleural drain. Finally, he died of respiratory failure due to bacterial pneumonia in the opposite normal lung one month after his second admission.

Macroscopic findings of the autopsied lung are shown in Fig. 6. The tumor originated in the right hilum, had a spreading form resembling a malignant pleural mesothelioma, and mainly occupied the pleural cavity. Microscopic findings (Hematoxylin-eosin staining) are shown in Fig. 7. The tumor was a moderately differentiated squamous cell carcinoma with keratinization. The results of immunohistochemical staining with anti-recombinant human G-CSF monoclonal antibody are shown in Fig. 8. The tumor cell cytoplasm stained positive and a final diagnosis of squamous cell carcinoma of the lung producing G-CSF was made.

\section{Discussion}

In 1976, Harwood et al reported six cases of primary adenocarcinoma of the lung that closely mimicked malignant pleural mesothelioma clinically and anatomically and that metastasized through the lymphogenous tract below the pleura or spread widely on the pleura through pleural effusion. They described it as a "pseudomesotheliomatous carcinoma" (5). However, the same spreading form has also been reported in cases of small cell carcinoma of the lung (6). Harwood et al noted that because adenocarcinomas tend to originate from the peripheral lung field and spread along the thickened scar of the pleura starting from a small nodule below the pleura, this spreading form was characteristic of cases of adenocarcinoma. However, we considered the possibility of the spread from right pleural effusion in the present case to be higher that the likelihood of hematogenous or lymphogenous transformation. The histological diagnosis of this case was squamous cell carcinoma and the mechanism of progression originated in the right upper bronchus. Direct invasion to pleura connecting with the intralobular pleura of the right upper-middle lobe and middle-lower lobe occurred. The form of invasion in this case; i.e., as an extension of squamous cell carcinoma evoked in the central portion, was interesting.

Another interesting finding in this case was the significant

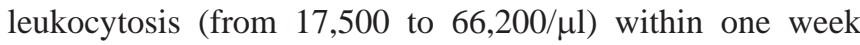
after the patient's second admission before the intrapleural injection of OK-432 and adriamycin. At first, we thouight this was only a complication of carcinomatous pleuritis. However, because the increase in his white blood cell count was recognized at admission, we suspected the complication of bacterial pneumonia and initiated administration of SPFX. Because significant leukocytosis continued despite degradation of C-reactive protein from 22.52 to $8.47 \mathrm{mg} / \mathrm{dl}$ after the administration of SPFX, we suspected that the final diagnosis might be a G-CSF-producing tumor, and found his serum G-CSF level to actually be elevated to $135 \mathrm{pg} / \mathrm{ml}$. There appears to have been little relationship between the intrapleural injection of OK-432 and adriamycin and the significant leukocytosis because his white blood cells had already 


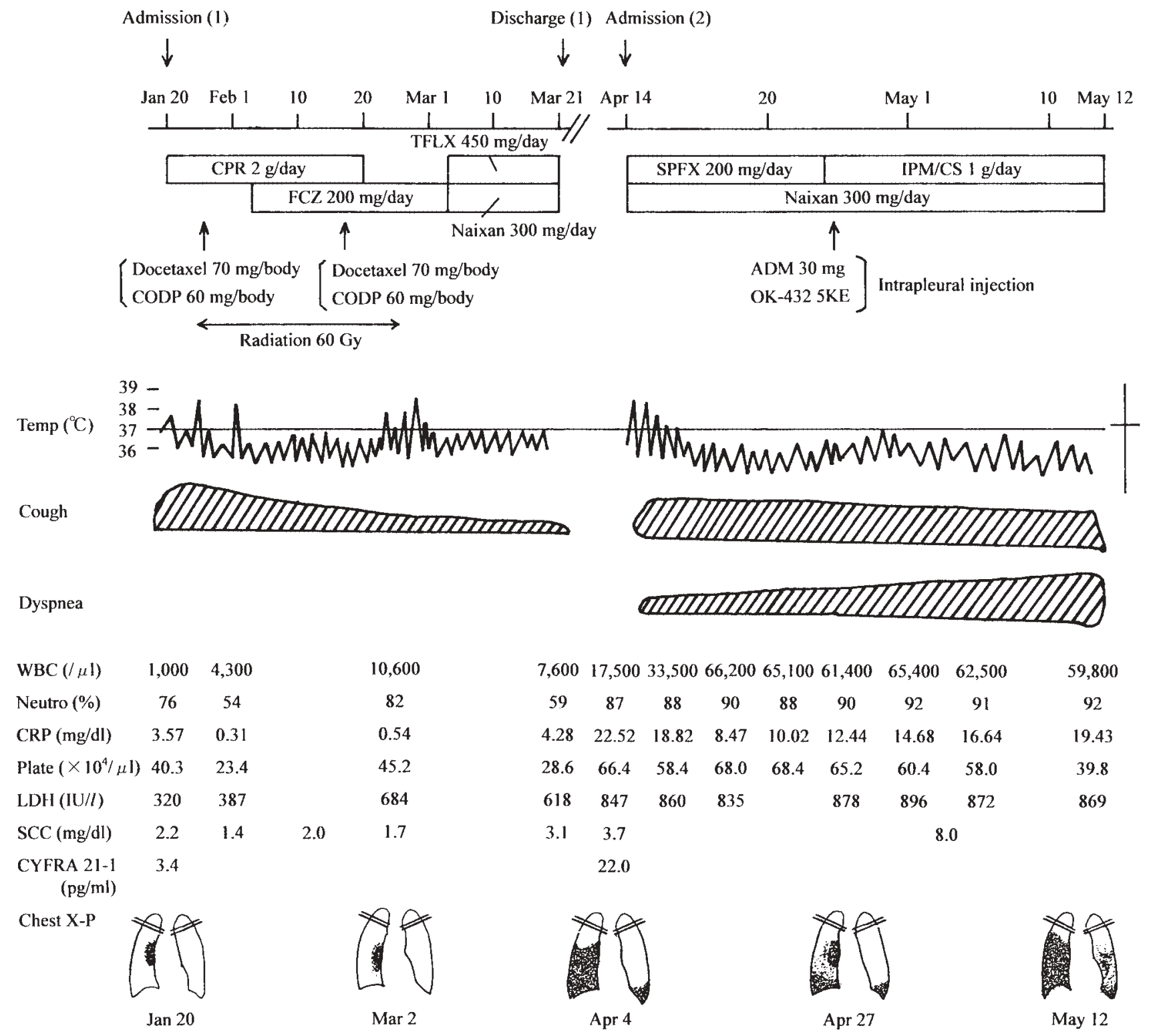

Figure 4. Clinical Course. 65. M. Lung cancer (Squamous cell carcinoma).

become elevated before the intrapleural injection. However, we suspected that the gene mutation which led to the development of G-CSF-producing tumor cells was influenced by both chemotherapy and radiation therapy because the significant leukocytosis appeared after treatment was completed. A diagnosis of G-CSF-producing tumor was finally made because the tumor cells from tissue obtained at autopsy were positive for G-CSF antibody immunohistochemically.

Since the first G-CSF producing tumor in lung cancer was reported by Asano et al (7) in 1977, about 40 cases have been reported. Yoshihara et al (8) reported the histological types of G-CSF-producing lung cancers and their percentages to be as follows; large cell carcinoma $62 \%$, squamous cell carcinoma $28 \%$, small cell carcinoma $5 \%$, and adeno- carcinoma 5\%. However, although Kasuga et al also (9) mentioned that G-CSF producing tumors were recognized in large cell carcinomas, they also found them in poorly differentiated non-small cell carcinomas. The lack of differentiation appears to be related to the production of G-CSF. In the present case, the final diagnosis of moderately differentiated squamous cell carcinoma differed from previous reports. Whereas G-CSF-producing tumors originating from other organs such as the stomach or pancreas have been found in moderately or well-differentiated carcinomas $(10,11)$, it is unknown why, until now, this has not been the case with lung cancer. Regarding the prognosis in cases of G-CSFproducing tumors, Yoshihara et al (8) observed that G-CSFproducing tumors progress rapidly and that the prognosis is 


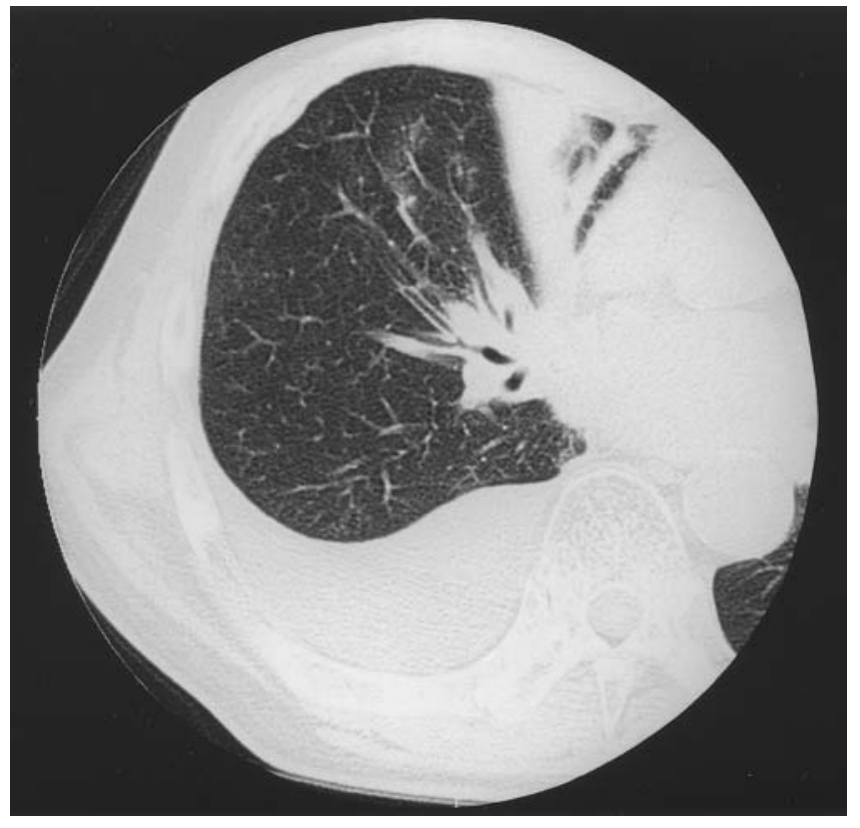

Figure 5. Chest CT scan at the time of radiation pneumonitis almost corresponding to the radiation area.

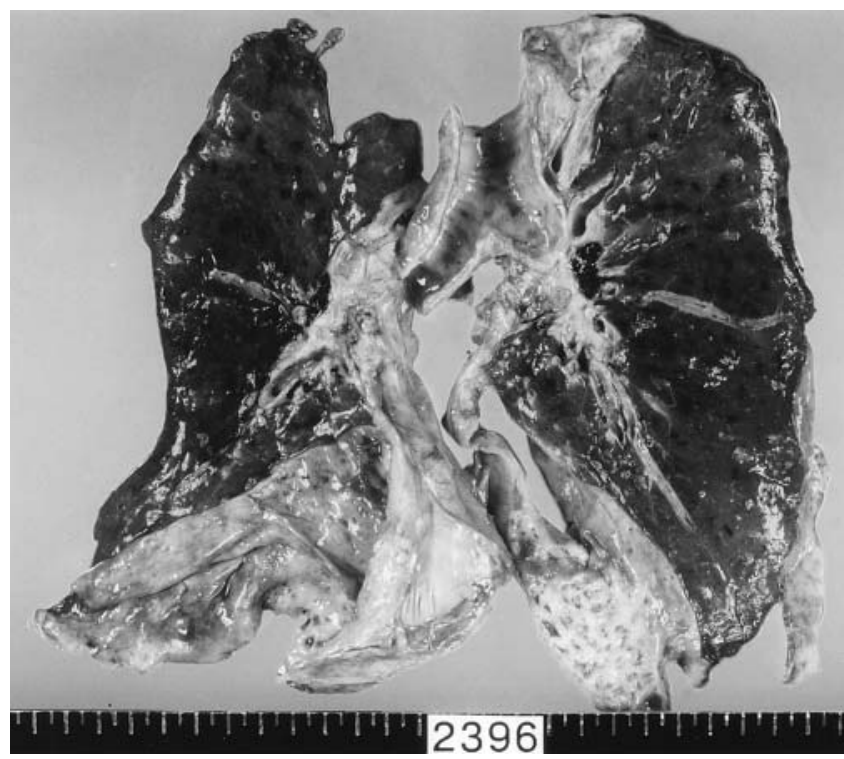

Figure 6. Macroscopic findings of lung cancer. The tumor originated from the right hilum and spread in a manner resembling a malignant pleural mesothelioma, mainly occupying the pleural cavity.

poor. These findings were compatible with the present case; no treatment was effective and he died within four months after the detection of lung cancer.

In conclusion, we reported an interesting case of a spreading of tumor which needed to be distinguished from malignant pleural mesothelioma. Although initially the histologi-

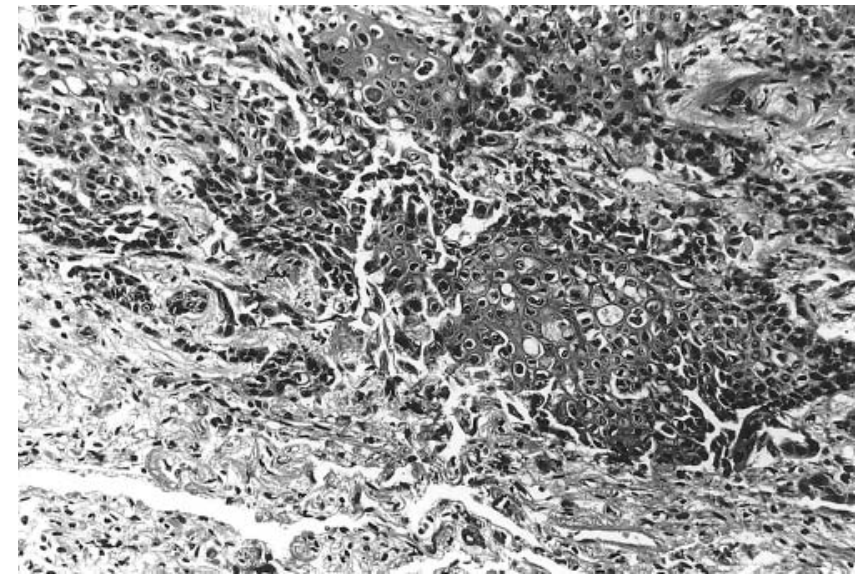

Figure 7. Microscopic findings showing moderatetly differentiated squamous cell carcinoma $(\mathrm{H}-\mathrm{E}$ stain, $\times 100)$.

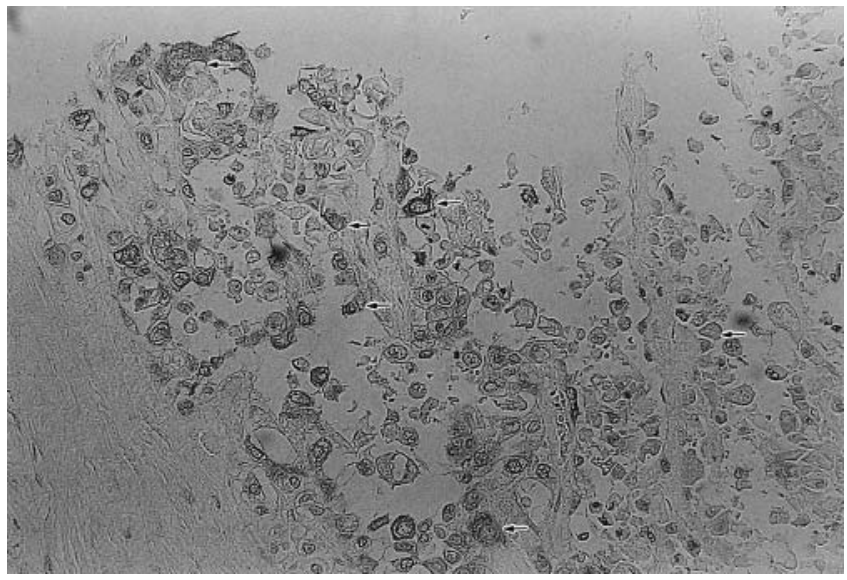

Figure 8. Immunohistochemical staining with anti-recombinant human G-CSF monoclonal antibody, showing positive staining in the cytoplasm of the tumor cells (arrows) (immunohistochemical staining, $\times 100$ ).

cal diagnosis had been moderately differentiated squamous cell carcinoma, the marked leukocytosis exhibited by the patient, as well as an elevated G-CSF level of $135 \mathrm{pg} / \mathrm{ml}$, led us to a final diagnosis of G-CSF-producing tumor.

\section{References}

1) Kurata T, Miyazawa T, Doi M, et al. A case of large cell carcinoma of the lung producing granulocyte colony-stimulating factor. Jpn J Lung Cancer 35: 187-193, 1995 (in Japanese, Abstract in English).

2) Koyama S, Sugiyama S, Doki Y, et al. A case of giant cell carcinoma of the lung accompanying hyperleukocytosis. Jpn J Lung Cancer 36: 41-47, 1996 (in Japanese, Abstract in English).

3) Kubo A, Yamaji Y, Fujita J, et al. A case of pseudomesotheliomatous adenocarcinoma of the lung. Gan No Rinsho 41: 837-842, 1995 (in Japanese, Abstract in English).

4) Nishimoto Y, Ohno T, Saito K. Pseudomesotheliomatous carcinoma of 


\section{KOBASHI et al}

the lung with histochemical and immunohistochemical study. Acta Pathol Jpn 33: 415-423, 1983.

5) Harwood TR, Gracey DR, Yokoo H. Pseudomesotheliomatous carcinoma of the lung. A variant of peripheral lung cancer. Am J Clin Pathol 65: 159-167, 1976

6) Maeda Y, Segawa Y, Takigawa N, et al. Two cases of small lung cancer presenting an unusual pattern of progression mimicking pleural mesothelioma. Int J Clin Oncol 3: 121-124, 1998.

7) Asano S, Urabe A, Okabe T, Sato N, Kondo Y. Demonstration of granulopoietic factors in the plasma of nude mice transplanted with a human lung cancer and in the tumor tissue. Blood 49: 845-852, 1977.

8) Yoshihara K, Fukuyama K, Okamura T, et al. An autopsy case of
CSF(colony-stimulating factor)-producing lung cancer and a review of the literature. Gan No Rinsho 32: 805-809, 1986 (in Japanese, Abstract in English).

9) Kasuga T, Saeki S, Yokoyama H, et al. A case of gastric cancer producing colony-stimulating factor. Gan No Rinsho 36: 2469-2474, 1990 (in Japanese, Abstract in English).

10) Saeki T, Saeki S, Yokoyama $H$, et al. A case of gastric cancer producing colony stimulating factor. Jpn J Cancer Clin 36: 2469-2474, 1990 (in Japanese, Abstract in English).

11) Ito $\mathrm{N}$, Matsuda $T$, Kakehi $S$, Takeuchi $E$, Takahashi $T$, Yoshida $O$. Bladder cancer producing granulocyte colony-stimulating factor. $\mathrm{N}$ Engl J Med 323: 1709-1710, 1990. 